OPEN ACCESS

Edited by:

Wen Zhou,

Case Western Reserve University, United States

Reviewed by: Delisha A. Stewart, University of North Carolina at Chapel Hill, United States Azadeh Nasrazadani, University of Pittsburgh Medical

Center, United States

*Correspondence:

Ghada Mohammed gmohammed@sharjah.ac.ae Noha A. Mousa noha.mousa@sharjah.ac.ae

Specialty section: This article was submitted to Cancer Endocrinology, a section of the journal

Frontiers in Endocrinology

Received: 22 September 2021 Accepted: 23 November 2021 Published: 17 December 2021

Citation:

Mohammed G, Mousa NA, Talaat IM, Ibrahim $\mathrm{H}$ and Saber-Ayad M (2021) Breast Cancer Risk with Progestin Subdermal Implants: A Challenge in Patients Counseling.

Front. Endocrinol. 12:781066. doi: 10.3389/fendo.2021.781066

\section{Breast Cancer Risk with Progestin Subdermal Implants: A Challenge in Patients Counseling}

\author{
Ghada Mohammed $^{1 *}$, Noha A. Mousa ${ }^{1 *}$, Iman M. Talaat ${ }^{1,2}$, Haya Ibrahim ${ }^{1}$ \\ and Maha Saber-Ayad ${ }^{1,3}$
}

${ }^{1}$ Clinical Sciences Department, College of Medicine, University of Sharjah, Sharjah, United Arab Emirates, ${ }^{2}$ Department of Pathology, Faculty of Medicine, Alexandria University, Alexandria, Egypt, ${ }^{3}$ Department of Medical Pharmacology, College of Medicine, Cairo University, Cairo, Egypt

There is a steady global rise in the use of progestin subdermal implants, where use has increased by more than 20 times in the past two decades. BC risk has been reported with the older progestin only methods such as oral pills, injectables, and intrauterine devices, however, little is known about the risk with subdermal implants. In this review, we aim to update clinicians and researchers on the current evidence to support patient counseling and to inform future research directions. The available evidence of the association between the use of progestin subdermal implants and BC risk is discussed. We provide an overview of the potential role of endogenous progesterone in BC development. The chemical structure and molecular targets of synthetic progestins of relevance are summarized together with the preclinical and clinical evidence on their association with $\mathrm{BC}$ risk. We review all studies that investigated the action of the specific progestins included in subdermal implants. As well, we discuss the potential effect of the use of subdermal implants in women at increased BC risk, including carriers of BC susceptibility genetic mutations.

Keywords: progestin, subdermal implants, breast cancer risk, etonogestrel, levonorgestrel

\section{INTRODUCTION}

Hormonal contraception is widely used by women of reproductive age, and its association with breast cancer (BC) risk has been investigated for decades. This risk has been extensively studied for estrogen-containing contraceptives which provides grounds for counseling women contemplating combined contraception (1-4). Meanwhile, conflicting or inadequate data has been published on progestin-only contraceptives (5).

The progestin-subdermal implants are increasingly popular progestin-only contraceptives since the first implant was licensed in 1983. They provide a highly effective, long-acting and reversible method of contraception (6). According to the National Institute for Health and Care Excellence (NICE), subdermal implants have a very low failure rate (less than 1 pregnancy per 1000 implants fitted over 3 years) (7). With their increasing popularity, clinicians are facing a challenge in counseling patients about the risk of $\mathrm{BC}$ associated with these methods. The current clinical guidelines do not provide adequate information to support clinicians or patients to make decisions regarding the use of these methods. 
In this review, we aim to update clinicians and researchers on the current evidence to support patient counseling and to inform future research directions. All found references on the association of progestin subdermal implants with BC risk were included in this review. As well, key studies (pre-clinical and clinical) on BC risk with endogenous progesterone and other progestin-containing contraceptives are overviewed. In addition to published research studies and clinical guidelines, we have also used the PubChem and the Human Protein Atlas databases to identify proteins (including receptors) for which progestins and progesterone have a high binding affinity.

\section{ENDOGENOUS PROGESTERONE IN NORMAL BREAST TISSUE}

Progesterone exerts its main physiological role by binding to the progesterone receptor (PR). The function of PR in the normal breast has been extensively studied (8). The resulting hormonereceptor complex initiates transcription of the target $\mathrm{PR}$ gene. This gene uses two specific promotors and starts sites for translation in the first exon to generate several transcripts, including protein-coding, and non-protein-coding transcripts. PR has two isoforms, PR-A and PR-B, derived from the same gene but induced by two different promoters, resulting in two sets of transcripts (9). Progesterone-dependent promoters were also shown to induce SRC-dependent MAPK signaling upon stimulation by progesterone (10). In addition, progesterone was shown to have a stimulatory effect on mitochondrial membrane potential and cellular respiration that can result in reduced apoptosis (11).

It is important to note that many, but not all of progesterone cellular actions are mediated through estrogen. They together coordinate the development of the ductal and lobular systems of the breast. Accordingly, there is a great challenge in identifying the individual actions of progesterone independently from those of estrogen $(12,13)$. Other factors can also add to such challenges including the receptor-independent effects of progesterone, its overlapping roles with androgens and prolactin, and the considerable variation of progesterone level during the menstrual cycle, pregnancy and perimenopause (14).

\section{ENDOGENOUS PROGESTERONE IN BC}

Various roles were assumed for the contribution of progesterone in $\mathrm{BC}$ development and progression $(5,15)$. These include immunomodulatory roles, paracrine stimulation of $\mathrm{BC}$ stem cells and the effect of progesterone metabolites (16-18). 4pregnanes and $5 \alpha$-pregnanes are examples of progesterone metabolites that were found to affect breast tissue. They are synthesized in different tissues including ovaries, adrenals and adipose tissue. $5 \alpha$-pregnanes can induce BC cell proliferation in vitro and is more abundant in $\mathrm{BC}$ tissue compared to normal breast tissue, whereas 4-pregnanes may have a suppressive effect on proliferation (19). However, little has been done to explore the clinical value of measuring circulatory progesterone metabolites or their exact correlation with $\mathrm{BC}$ risk and prognosis (5).

PR-B is currently recognized for its role in breast carcinogenesis, and it appears to be involved in the regulation of more genes in BC cells than PR-A. Furthermore, it mediates cell cycle progression through extranuclear signalling, unlike isoform A which is limited to the nucleus $(20,21)$. Moreover, knocking out the PR-B isoform in the mammary mouse model led to abnormal mammary gland development which did not occur when PR-A was knocked out (22). There is lacking data on the preferential binding of synthetic progestins to either PR-A or PR-B. However, Schindler et al. suggested that no differences are expected to show since both isoforms have identical steroidbinding domains (23).

Based on the available evidence that progesterone possibly plays a role in $\mathrm{BC}$, the potential therapeutic effect of antiprogesterone medications were studied (24). Despite the proof of principle, those studies remain limited hindering their wide clinical use as adjunct endocrine therapies or as chemopreventive agents. Noteworthy, recent expert views - as thoroughly discussed by Horwitz and Carol- are proposing that endogenous progesterone should not be considered a breast carcinogen in the case of the normal breast (25).

\section{PROGESTINS IN CLINICAL USE: (STRUCTURE AND FUNCTION)}

Progestins or progestagens are terminologies often used alternatively to describe synthetic exogenous compounds with progesterone-like action. Progestins are generally classified into C-21 compounds (chemically close to the structure of endogenous progesterone with 21 carbon atoms) and C-19 compounds (chemically close to the structure of testosterone with 19 carbon atoms) (26).

The most common progestin preparations are those used as contraceptives. Progestins are also used as a key component of hormone replacement therapy (HRT) (27). The proven antiproliferative effect of progesterone on the endometrial tissue reduces the risk of endometrial hyperplasia and endometrial cancer in women using such therapy (28). However, there is no evidence that such a favorable effect is maintained in the case of the breast tissue. In addition, progestins are widely used during early pregnancy in patients with threatened miscarriage and patients undergoing assisted reproduction as it is believed to provide luteal phase support and hence reduces the risk of early pregnancy loss $(29,30)$.

\section{PROGESTIN SUBDERMAL IMPLANTS}

\section{Overview and Structure}

Multiple subdermal implants, with different progestin types, were initially introduced in different countries, however, only a few are currently commercially available for use worldwide, 
while others have been either discontinued or in limited use (31, 32). These most popular subdermal implants contain one of two progestins: levonorgestrel (LNG) or etonogestrel (ENG) as outlined in Box 1. Detailed structural differences can be reviewed in Table 1, as outlined in the PubChem database (https://pubchem.ncbi.nlm.nih.gov/). Of note, ENG is an active metabolite of desogestrel, which has been more widely used in oral formulations. In this review, we focus on these two implants, both shown to have comparable effectiveness, release characteristics and pharmacokinetics (6).

\section{Identification of Cellular Targets of Progestins in Subdermal Implants}

To understand how progestins in subdermal implants may differ from endogenous progesterone in terms of potential breast carcinogenesis, it is necessary to identify their main cellular

BOX 1 | Progestin Subdermal Implants in Commercial Use.

\begin{tabular}{lcc}
\hline Progestin type & Generic name & Duration of effect \\
\hline$L N G$ & Norplant & 5 years \\
LNG & Jadelle & 5 years \\
LNG & Sino-implant2 & 4 years \\
$E N G$ & Implanon & 3 years \\
ENG & Nexplanon & 3 years
\end{tabular}

targets. We used the PubChem database to identify the proteins (including receptors) for which LNG, ENG, and progesterone have a high binding affinity (36). In common, the three compounds bind to the progesterone receptors (PGR), androgen (AR), and estrogen-1 (ESR1) as outlined in the following Venn diagram (Figure 1).

In addition, we searched the human protein atlas (http:// www.proteinatlas.org/, tissue atlas section) (37) to retrieve the expression of proteins highly expressed in the normal breast tissue to which progesterone has a high binding affinity (38). Out of those proteins, progesterone mainly binds to 3 proteins, namely; TARDBP, MAPK1 and NR3C1. LNG also binds, with high affinity, to NR3C1. Using the STRING protein functional analysis network (39), annotations of these proteins and the RNA expression of other proteins with progesterone high binding affinity are summarized (Table 2 and Supplemental Figures S1-S9).

Relevant to the discussion on cellular targets, both LNG and ENG have an affinity to AR (as shown in Figure 1). The $\mathrm{AR}$ is expressed in $70-90 \%$ of BC tissue samples (49). However, in BC patients there is ongoing controversy on the paradoxical role of AR (50). It appears that AR has a tumor suppressor effect (51), mostly in ER-positive BC, whereas it plays an oncogenic role in ER-negative BC, mainly mediated by FOXA1 $(52,53)$. This data adds to the complexity of

TABLE 1 | Chemical structure of progestins included in subdermal implants.

\begin{tabular}{lll}
\hline Progestin & Chemical formula & Detailed structure
\end{tabular}

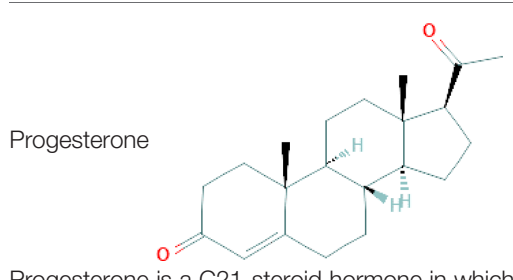

Progesterone is a C21-steroid hormone in which a pregnane skeleton carries oxo substituents at positions 3 and 20 and is unsaturated at C (4)-C. It is a 20-oxo steroid, a 3-oxo-Delta steroid and a C21-steroid hormone (33)

Levonorgestrel

(Oral pills, IUS, Implants)

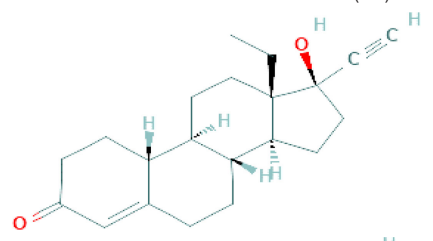

Desogestrel (Oral pills)

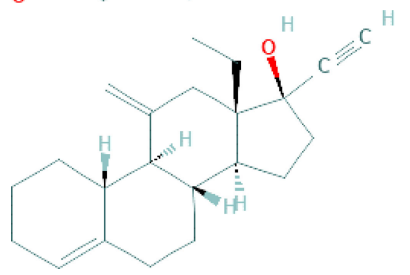

Desogestrel, a semi-synthetic compound and a prodrug, is a third-generation progestogen and hence, a member of the gonane family. It is a 17 beta-hydroxy synthetic progestogen structurally related to levonorgestrel, with PR agonistic activity (23)
A 17-betahydroxy steroid, a 3-oxo-Delta (4) synthetic progestogen and levorotatory form of norgestrel. It displays progestational and androgenic activity, but it lacks estrogen-like activity. Levonorgestrel binds to the progesterone receptor in the nucleus of target cells (34).
Etonogestrel (Subdermal implants)

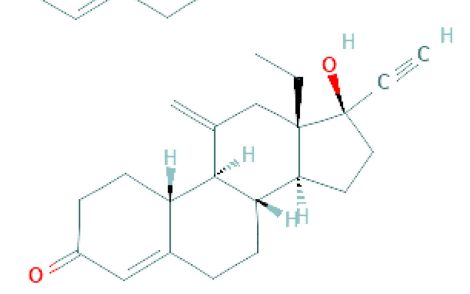

Etonogestrel molecule is a 3-keto-desogestrel or 19-nortestosterone which is a synthetic biologically active metabolite of desogestrel (35) 


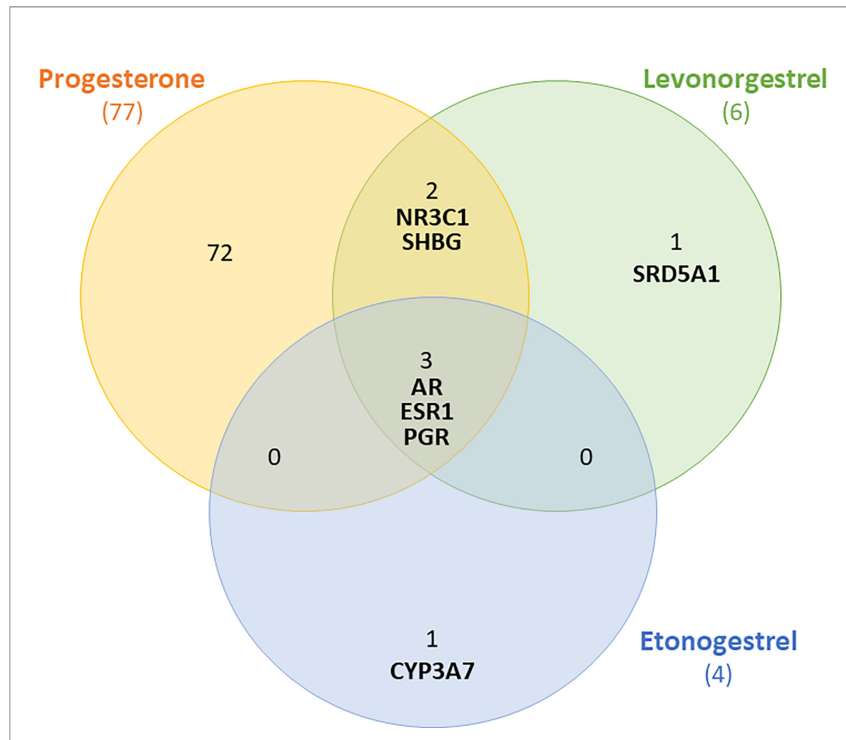

FIGURE 1 | Venn diagram showing receptors to which levonorgestrel, etonogestrel and progesterone can bind with high affinity. Shared receptors include androgen (AR), estrogen-1(ESR1) and progesterone receptors (PGR).

predicting the effect of any pharmacologic agent with a high affinity to AR since we would not be certain if its pro or antitumor role will be activated in a normal breast. Nevertheless, a case-control study of women with benign breast conditions showed no correlation between AR expression in the normal breast tissue and subsequent risk of developing BC (54). This finding may be slightly assuring, however, it did not directly examine the effect of exogenous androgens on $\mathrm{BC}$ risk in healthy women.

\section{PROGESTIN-ONLY CONTRACEPTION AND BC RISK}

\section{Evidence From Pre-Clinical Studies}

The notion of progestins to initiate BC tumors appears to be derived from early experimental toxicity studies (2, 55). For instance, Depot Medroxy Progesterone Acetate (DMPA) has been tested for its carcinogenic effect in mice, where it induced mammary adenocarcinomas and in dogs where it induced mammary hyperplasia $(56,57)$. Based on a review of the FDA records, LNG has been evaluated for its BC risk in animal studies with no evidence of carcinogenicity. Different doses of LNG were tested in beagles and rhesus monkeys for several years without evidence of inducing mammary gland malignancies. However, evaluation of the long-term toxicity of desogestrel on mice and rats showed a higher rate of mammary adenocarcinoma associated with higher doses (55).

\section{Evidence of the Effect of Progestins on Mammographic Breast Density}

Mammographic breast density (MBD) is recognized as an independent marker for $\mathrm{BC}$ risk $(58,59)$. Moreover, MBD appears to be a modifiable risk factor in response to reproductive and lifestyle modifications $(60,61)$, as well as to hormonal and antihormonal therapies. Therefore, it has been used as an intermediate marker to evaluate the effect of risk-increasing $(62,63)$ and riskreducing interventions (64-67). As a result, MBD has been often used to evaluate breast safety of newly introduced hormonal therapies, such as selective estrogen receptor modulators (SERM), selective progesterone receptor modulators (SPRM), aromatase inhibitors, gonadotropin-releasing hormone $(\mathrm{GnRH})$ agonists, and phytoestrogens (68).

TABLE 2 | Annotations of proteins to which progesterone have a high affinity.

Protein

Annotation

Expression

TARDBP TAR DNA-binding protein is DNA and RNA-binding protein, regulating transcription and splicing It may be involved in the synthesis of microRNA, apoptosis and cell division (40).

MAPK1 Mitogen-activated protein kinase 1 is also a Ser/Thr-kinase and an essential component of the MAP kinase signal transduction pathway. The MAPK/ERK cascade exerts a contextual role depending on the cellular environment. It mediates a variety of biological activities such as cell growth, adhesion, survival, and differentiation (41).

NR3C1 Nuclear Glucocorticoid receptor. It has transcriptional repression activity. It has the least effect on transcriptional activation, compared to the activity of all isoforms (42).

RNA

Expression

NME2 Nucleoside diphosphate kinase; NME2 has a major role in the synthesis of nucleoside triphosphates (GTP, CTP and TTP but not ATP). It suppresses Rho activity by interacting with AKAP13/LBC. Rho (GTPases) are indirectly linked to cancer by their interaction with known oncogenes (e.g. Raf and Ras), (43). NME2 also acts as a transcriptional activator of the MYC gene.

PTEN Phosphatase and tensin homolog; It is a tumor suppressor with a lipid phosphatase activity. Inactivation of PTEN lipid phosphatase leads to the interaction of the Hippo and PI3K/Akt pathways, thus promoting tumorigenesis (44).

CDKN1B Cyclin-dependent kinase inhibitor $1 \mathrm{~B}$ is one of the key regulators of the progression of the cell cycle. It inhibits the kinase activity of CDK2 bound to cyclin A, leading to G1 arrest. It also markedly inhibits cyclin E- and cyclin A- CDK2 complexes (45).

RXRA Retinoic acid receptor RXR-alpha. Such receptors bind as heterodimers to their target response elements in response to their ligands to regulate gene expression (46).

OXTR Oxytocin receptor, a G protein-coupled receptor that mediates various effects of oxytocin (47).

CDK4 Cyclin-dependent kinase 4 is Ser/Thr-kinase component of cyclin D-CDK4 (DC) complexes. It phosphorylate and inhibit members of the retinoblastoma (RB) protein family including RB1 and regulate the cell-cycle during G (1)/S transition. Cyclin D-CDK4 complexes play a key role in cell cycle progression (48). 
In postmenopausal women, there is substantial evidence that progestin-containing HRT increases MBD in comparison to estrogen alone HRT or placebo (69-71). In reproductive age and premenopausal women, multiple studies investigated the effect of combined estrogen and progestin contraceptives on MBD (72). However, when it comes to the use of progestinonly contraceptives in reproductive age women, limited quality evidence indicated variable outcomes of their effect on MBD. For example, the use of the levonorgestrel intrauterine system (LNG-IUS) led to an increased MBD after one and a half years in one report (73), whereas the discontinuation of DMPA injection led to increased MBD in another report (74). A similar MBD-reducing effect was observed in a small study of 26 women who were given micronized progesterone in the luteal phase for 6 months (75). There have been no studies on the effect of progestincontaining subdermal implants on MBD. Such scarce evidence is difficult to interpret or to further rely on during patient counseling. The extrapolation from postmenopausal studies or from studies that included combined estrogen and progesterone would not be optimally valid.

\section{Evidence From Clinical Studies}

In postmenopausal women, the long term use of progestincontaining HRT was associated with increased BC risk (76). In women of reproductive age, progestin-only contraceptives including oral pills, injectables, intrauterine devices and implants, were evaluated for their association with BC risk in multiple large-scale clinical studies with variable outcomes as summarized in Table 3 (1, 77-79, 83).

Various Progesterone-Only Pills (POPs) have been investigated for their association with $\mathrm{BC}$ risk. Norethindrone, levonorgestrel and desogestrel POPs are the most widely studied. In the Norwegian-Swedish Women's Lifestyle and Health Cohort Study (including 103,027 women), the exclusive ever use of POPs was not associated with increased BC risk, while the current or recent use of POPs was found to increase the risk of BC (78). Mørch and colleagues conducted a nation-wide analysis of the Danish registries which included 1.8 million women throughout 11 years of follow-up. They investigated BC risk in relation to current and previous hormonal contraceptive use. Compared to never using hormonal contraception, levonorgestrel-containing
POPs were associated with significantly increased BC risk (RR: 1.93). However, norethindrone and desogestrel-containing POPs were not associated with increased risk of BC in the same study (1). Likewise, the progestin-only injectables in the form of DMPA were found in some case-control studies to be associated with an increased risk of invasive BC (80). Other studies did not confirm this association $(1,79)$.

The LNG-IUS is a highly popular effective method of contraception and is also widely used for the management of menorrhagia. It releases a minute daily dose of LNG into the uterine cavity leading to high LNG concentration in the endometrium (84). For a long time, LNG-IUS has been perceived by physicians as a local method of a very minimal systemic effect. Earlier studies reported no evidence of increased $\mathrm{BC}$ risk with using this method $(85,86)$ and it was included in studies of BC patients (87). However, recent evidence demonstrated an association of LNG-IUS and increased BC risk (A relative risk of around 1.2 was reported) $(1,81)$. This risk can be explained by the evidence of significant systemic LNG concentration, reaching roughly half the level achieved with oral formulations $(88,89)$. Yet, these studies carry limitations including the relatively small number of users and the consideration of the confounding factors such as the prior use of combined oral contraceptives (COCs) (90).

When it comes to progestin-only subdermal implants, scarce data is available on their association with BC risk. Thus far, there has been no dedicated clinical study to evaluate this risk with subdermal implants. However, a few studies included users of subdermal contraceptive implants among other types of contraception. In the study by Mørch and colleagues, nine BC events were found out of 42,217 person-years of using subdermal implants, with an insignificant relative risk of 0.93 (1). Similarly a case control study including 4,575 women with BC and 4,682 controls, evaluated the usage of progestin injectables and progestin implants with $\mathrm{BC}$ risk. Five of twelve women who used progestin implants developed $\mathrm{BC}$, however, this was not a statistically significant risk (79). Nevertheless, in a large casecontrol study conducted in the United States, where less than 1\% of the study population used subdermal implants, the risk of BC was found to be increased by more than 8 -fold in the implant users (82). Apparantly, all these studies included a limited number of implant users relative to the other studied hormonal contraceptives.

TABLE 3 | Summary of key evidence on BC risk with progestin-only contraceptives.

Progestin

Progestin Only Pills (POPs)

various progestin types

Depo Medroxy Progesterone Acetate (DMPA) injectable

Levonorgestrel Intrauterine system (LNG-IUS)

Progestin-only subdermal implants (LNG or ENG)
BC Risk Evidence

No significant risk

OR 0.9 (95\% Cl not reported) (77)

RR 1.1 (95\% Cl: 0.8-1.7) (78)

No significant risk $(1,79)$

Increased risk (RR 2.2) (80)

Increased risk (recent studies)

RR $1.21(95 \% \mathrm{Cl}, 1.11$ to 1.33$)$ (1)

RR 1.19 (95\% Cl, 1.13-1.25) (81)

8-fold increased risk (82) (older study, limited sample)

No significant risk $(1,79)$ (recent studies, relatively limited sample) 
In regards to the effect of dose and duration of progestin-only contraceptives on $\mathrm{BC}$ risk, an increased risk of $\mathrm{BC}$ was suggested in some studies (82), while not confirmed by others (1). For the LNG-IUS, the reported increase in BC risk by Mørch and colleagues was interestingly not affected by the duration of use. Nevertheless, an earlier nation-wide study of a Finnish cohort by Soini and colleagues suggested an increased risk with the extended duration of use of LNG-IUS (81). Such inconsistency adds again to the difficulty in counseling patients on the safe duration of use. For subdermal implants, there is no data available on the dose or duration-response relationship.

\section{PROGESTERONE AND BC SUSCEPTIBILITY GENETIC MUTATION CARRIERS}

An important study by Yongxian Ma et al. showed that BRCA1 inhibits the PR activity and the knock-out of the BRCA1 gene could enhance the progesterone-stimulated PR activity. This indicates that BRCA1 is an important suppressor of the PR activity and its mutated form is not able to maintain such suppression (91). BRCA1 and 2 mutation carriers seem to additionally have an altered $\mathrm{PR}$ expression in breast tissue compared to non-carrier women. There is evidence of the loss of the $\mathrm{B}$ isoform leaving predominance to the $\mathrm{A}$ isoform, which led to premalignant lesions and invasive BC disease (92). Furthermore, the breast tissue of BRCA1 mutation carriers may have a different organization or composition of the extracellular matrix (93). Taken together, these studies may suggest that the response of BRCA 1 and 2 mutation carriers to exogenous progesterone may be exaggerated. In clinical terms, those women may be hypersensitive to progestin preparations in general.

In the context of clinical studies, interestingly, there is evidence that BRCA1/2 mutation carriers could be exposed to significantly higher levels of serum progesterone during the luteal phase of the menstrual cycle (reported to be around $121 \%$ higher than in matched control women) (94). In addition, using progestin-containing HRT in BRCA1 mutation carriers who underwent prophylactic oophorectomy carried an increased BC risk compared to using estrogen alone HRT (22\% vs $12 \%$ cumulative risks) (95). This is in line with the findings of the Women's Health Initiative (WHI) study in non-carrier women (76). Combined oral contraceptive pills, were also found to increase the risk of BC in BRCA1 mutation carriers, especially if used more than 5 years or in younger women less than 30 years old (96). Similar findings were shown with both BRCA1 and BRCA2 mutation carriers who ever used combined oral contraceptive pills. Likewise, since there are no studies of the effect of progestin-only containing subdermal implants, it remains difficult to accurately counsel those young patients on the safety of these contraceptives. The UK Medical Eligibility Criteria for Contraceptive Use (UKMEC) considers subdermal implants and other progestin-only contraceptives as category 2 in BRCA1/2 mutation carriers ("UKMEC Category 2:
A condition where the advantages of using the method generally outweigh the theoretical or proven risks") (97). However, both the pre-clinical and clinical studies mentioned above do not seem to support this categorization. Until more conclusive evidence exists, we may suggest that clinicians should adopt a cautious approach towards prescribing progestin-containing contraceptives in this special group of women who already have a very high baseline $\mathrm{BC}$ risk.

\section{CLINICAL AND RESEARCH EVIDENCE FOR PATIENT COUNSELING}

Limited evidence is available on the risk of $\mathrm{BC}$ associated with contraceptive implants. The available limited number of studies, showed no significant increased risk. However, if the risk of BC associated with the LNG-IUS is considered, it is difficult to completely dismiss the possibility of a comparable risk with the LNG and ENG implants. A recent review has addressed the counseling of women on the risk of BC with hormonal contraceptives, however, did not include subdermal implants (98).

The Faculty of Sexual and Reproductive Healthcare (FSRH) published recent guidelines on the ENG contraceptive implant. They suggested no significant increase risk of BC, however, they highlighted the limited available data to exclude such an association (99). The recently revised practice advisory by the American College of Obstetricians and Gynecologists (ACOG) analyzed the outcomes of the large cohort study by Mørch and colleagues and other evidence on the risk of $\mathrm{BC}$ with hormonal contraceptives. In brief, the ACOG concludes that BC risk with progestin-only contraceptives remains inconsistent. There was no observed increased risk with contraceptive implants, while the risk with LNG-IUS was comparable to that of oral contraceptives. However, the ACOG has also highlighted the limitations of the study and the difficulty in justifying the absence of risk related to dosage and duration of use (100). The ACOG presented a few points of advice to guide physicians while counseling women on BC risk with hormonal contraceptives. However, they did not specify any advice on subdermal implants.

\section{CONCLUSION}

There is an obvious lack of clinical guidelines or solid research data on the safety of progestin subdermal implants. This left physicians with a challenge in providing counseling for women interested in starting these methods, or current users who consider using them long-term. A shared decision between the physician and the patient should highlight our inability to guarantee $\mathrm{BC}$ relevant safety. Weighing benefits versus risks for each patient based on her own baseline BC risk seems a valid approach at this stage. Hereditary and acquired risk factors (e.g. reproductive factors and obesity) that may potentiate any small added risk using these methods should be considered. Since all previous studies did not focus on subdermal implants, 
conclusions will remain controversial until dedicated welldesigned studies are conducted.

\section{AUTHOR CONTRIBUTIONS}

GM wrote the first draft, edited, and reviewed the manuscript. NM contributed to the concept, edited, and review the manuscript. MS-A contributed to specialized sections, editing, and review of the manuscript. IT contributed to specialized

\section{REFERENCES}

1. Mørch LS, Skovlund CW, Hannaford PC, Iversen L, Fielding S, Lidegaard Ø. Contemporary Hormonal Contraception and the Risk of Breast Cancer. N Engl J Med (2017) 377:2228-39. doi: 10.1056/NEJMoa1700732

2. I.A.f.R.o.C. (IARC). IARC Monographs on the Evaluation of Carcinogenic Risks to Humans, No. 72. In: IARC Working Group on the Evaluation of Carcinogenic Risks to Humans. Hormonal Contraception and Post-Menopausal Hormonal Therapy. France: Lyon (FR (1999). Available at: https://www.ncbi. nlm.nih.gov/books/NBK396191/.

3. Karlsson T, Johansson T, Hoglund J, Ek WE, Johansson A. Time-Dependent Effects of Oral Contraceptive Use on Breast, Ovarian, and Endometrial Cancers. Cancer Res (2021) 81:1153-62. doi: 10.1158/0008-5472.CAN-20-2476

4. Hunter DJ, Colditz GA, Hankinson SE, Malspeis S, Spiegelman D, Chen W, et al. Oral Contraceptive Use and Breast Cancer: A Prospective Study of Young Women. Cancer Epidemiol Biomarkers Prev (2010) 19:2496-502. doi: 10.1158/ 1055-9965.EPI-10-0747

5. Trabert B, Sherman ME, Kannan N, Stanczyk FZ. Progesterone and Breast Cancer. Endocr Rev (2020) 41:320-44. doi: 10.1210/endrev/bnz001

6. Croxatto HB. Mechanisms That Explain the Contraceptive Action of Progestin Implants for Women. Contraception (2002) 65:21-7. doi: 10.1016/S0010-7824 (01)00294-3

7. NICE(UK). Addendum to Clinical Guideline 30, Long-Acting Reversible Contraception. London: National Institute for health and Care Excellence (NICE). (2014).

8. Obr AE, Edwards DP. The Biology of Progesterone Receptor in the Normal Mammary Gland and in Breast Cancer. Mol Cell Endocrinol (2012) 357:4-17. doi: 10.1016/j.mce.2011.10.030

9. Jacobsen BM, Richer JK, Sartorius CA, Horwitz KB. Expression Profiling of Human Breast Cancers and Gene Regulation by Progesterone Receptors. J Mammary Gland Biol Neoplasia (2003) 8:257-68. doi: 10.1023/B: JOMG.0000010028.48159.84

10. Proietti C, Salatino M, Rosemblit C, Carnevale R, Pecci A, Kornblihtt AR, et al. Progestins Induce Transcriptional Activation of Signal Transducer and Activator of Transcription 3 (Stat3) via a Jak-And Src-Dependent Mechanism in Breast Cancer Cells. Molecular and Cellular Biology (2005) 25:4826-40. doi: 10.1128/MCB.25.12.4826-4840.2005

11. Behera MA, Dai Q, Garde R, Saner C, Jungheim E, Price TM. Progesterone Stimulates Mitochondrial Activity With Subsequent Inhibition of Apoptosis in MCF-10A Benign Breast Epithelial Cells. Am J Physiol Endocrinol Metab (2009) 297:E1089-96. doi: 10.1152/ajpendo.00209.2009

12. Hilton HN, Clarke CL, Graham JD. Estrogen and Progesterone Signalling in the Normal Breast and its Implications for Cancer Development. Mol Cell Endocrinol (2018) 466:2-14. doi: 10.1016/j.mce.2017.08.011

13. Hewitt SC, Korach KS. Progesterone Action and Responses in the aerko Mouse. Steroids (2000) 65:551-7. doi: 10.1016/S0039-128X(00)00113-6

14. Lange CA. Challenges to Defining a Role for Progesterone in Breast Cancer. Steroids (2008) 73:914-21. doi: 10.1016/j.steroids.2007.12.023

15. Hagan CR, Lange CA. Molecular Determinants of Context-Dependent Progesterone Receptor Action in Breast Cancer. BMC Med (2014) 12:1-9. doi: 10.1186/1741-7015-12-32

16. Joshi PA, Jackson HW, Beristain AG, Di Grappa MA, Mote PA, Clarke CL, et al. Progesterone Induces Adult Mammary Stem Cell Expansion. Nature (2010) 465:803-7. doi: 10.1038/nature09091 sections of the manuscript. HI contributed to searching and presenting protein atlas data. All authors contributed to the article and approved the submitted version.

\section{SUPPLEMENTARY MATERIAL}

The Supplementary Material for this article can be found online at: https:/www.frontiersin.org/articles/10.3389/fendo.2021.781066/ full\#supplementary-material

17. Axlund SD, Sartorius CA. Progesterone Regulation of Stem and Progenitor Cells in Normal and Malignant Breast. Mol Cell Endocrinol (2012) 357:71-9. doi: 10.1016/j.mce.2011.09.021

18. Werner LR, Gibson KA, Goodman ML, Helm DE, Walter KR, Holloran SM, et al. Progesterone Promotes Immunomodulation and Tumor Development in the Murine Mammary Gland. J Immunother Cancer (2021) 9:e001710. doi: 10.1136/jitc-2020-001710

19. Wiebe JP, Muzia D, Hu J, Szwajcer D, Hill SA, Seachrist JL. The 4-Pregnene and $5 \alpha$-Pregnane Progesterone Metabolites Formed in Nontumorous and Tumorous Breast Tissue Have Opposite Effects on Breast Cell Proliferation and Adhesion. Cancer Res (2000) 60:936-43.

20. Kariagina A, Aupperlee MD, Haslam SZ. Progesterone Receptor Isoform Functions in Normal Breast Development and Breast Cancer. Crit Rev ${ }^{\mathrm{TM}}$ Eukaryot Gene Expression (2008) 18:11-33. doi: 10.1615/CritRevEukarGeneExpr. v18.i1.20

21. Boonyaratanakornkit V, McGowan E, Sherman L, Mancini MA, Cheskis BJ, Edwards DP. The Role of Extranuclear Signaling Actions of Progesterone Receptor in Mediating Progesterone Regulation of Gene Expression and the Cell Cycle. Mol Endocrinol (2007) 21:359-75. doi: 10.1210/me.2006-0337

22. Mulac-Jericevic B, Lydon JP, DeMayo FJ, Conneely OM. Defective Mammary Gland Morphogenesis in Mice Lacking the Progesterone Receptor B Isoform. Proc Natl Acad Sci (2003) 100:9744-9. doi: 10.1073/pnas.1732707100

23. Schindler AE, Campagnoli C, Druckmann R, Huber J, Pasqualini JR, Schweppe KW, et al. Reprint of Classification and Pharmacology of Progestins. Maturitas (2008) 61:171-80. doi: 10.1016/j.maturitas.2008.11.013

24. Singhal H, Greene ME, Tarulli G, Zarnke AL, Bourgo RJ, Laine M, et al. Genomic Agonism and Phenotypic Antagonism Between Estrogen and Progesterone Receptors in Breast Cancer. Sci Adv (2016) 2:e1501924. doi: 10.1126/sciadv.1501924

25. Horwitz KB, Sartorius CA. 90 YEARS OF PROGESTERONE: Progesterone and Progesterone Receptors in Breast Cancer: Past, Present, Future. J Mol Endocrinol (2020) 65:T49-63. doi: 10.1530/JME-20-0104

26. Stanczyk FZ, Hapgood JP, Winer S, Mishell DRJr. Progestogens Used in Postmenopausal Hormone Therapy: Differences in Their Pharmacological Properties, Intracellular Actions, and Clinical Effects. Endocr Rev (2013) 34:171-208. doi: 10.1210/er.2012-1008

27. NICE. Menopause: Diagnosis and Management. In: NICE Guideline 23. 2015 London: National Institute for Health and Care Excellence (NICE) (2015). Available at: www.nice.org.uk/ng23.

28. Kim JJ, Kurita T, Bulun SE. Progesterone Action in Endometrial Cancer, Endometriosis, Uterine Fibroids, and Breast Cancer. Endocr Rev (2013) 34:130-62. doi: 10.1210/er.2012-1043

29. Daya S. Luteal Support: Progestogens for Pregnancy Protection. Maturitas (2009) 65(Suppl 1):S29-34. doi: 10.1016/j.maturitas.2009.09.012

30. Wahabi HA, Fayed AA, Esmaeil SA, Bahkali KH. Progestogen for Treating Threatened Miscarriage. Cochrane Database Syst Rev (2018) 8:CD005943CD005943. doi: 10.1002/14651858.CD005943.pub5

31. Meirik O, Fraser IS, d'Arcangues C. Implantable Contraceptives for Women. Hum Reprod Update (2003) 9:49-59. doi: 10.1093/humupd/dmg004

32. Rowlands S, Searle S. Contraceptive Implants: Current Perspectives. Open Access J Contracept (2014) 5:73-84. doi: 10.2147/OAJC.S55968

33. National Center for Biotechnology Information. PubChem Compound Summary for CID 5994, Progesterone. Maryland:National Library of Medicine. (2021). Retrieved November 30, 2021. 
34. Lemus AE, Vilchis F, Damsky R, Chávez BA, GARCiA GA, Grillasca I, et al. Mechanism of Action of Levonorgestrel: In Vitro Metabolism and Specific Interactions With Steroid Receptors in Target Organs. J Steroid Biochem Mol Biol (1992) 41:881-90. doi: 10.1016/0960-0760(92)90442-L

35. Drugbank, Etonogestrel (2021). Available at: https:/go.drugbank.com/drugs/ DB00294.

36. Kim S, Chen J, Cheng T, Gindulyte A, He J, He S, et al. PubChem in 2021: New Data Content and Improved Web Interfaces. Nucleic Acids Res (2020) 49: D1388-95. doi: 10.1093/nar/gkaa971

37. Uhlen M, Fagerberg L, Hallstrom BM, Lindskog C, Oksvold P, Mardinoglu A, et al. Proteomics. Tissue-Based Map of the Human Proteome. Science (2015) 347:1260419. doi: 10.1126/science.1260419

38. Yu NY, Hallström BM, Fagerberg L, Ponten F, Kawaji H, Carninci P, et al. Complementing Tissue Characterization by Integrating Transcriptome Profiling From the Human Protein Atlas and From the FANTOM5 Consortium. Nucleic Acids Res (2015) 43:6787-98. doi: 10.1093/nar/gkv608

39. Szklarczyk D, Gable AL, Lyon D, Junge A, Wyder S, Huerta-Cepas J, et al. Mering, STRING V11: Protein-Protein Association Networks With Increased Coverage, Supporting Functional Discovery in Genome-Wide Experimental Datasets. Nucleic Acids Res (2018) 47:D607-13. doi: 10.1093/nar/gky1131

40. Ke H, Zhao L, Zhang H, Feng X, Xu H, Hao J, et al. Loss of TDP43 Inhibits Progression of Triple-Negative Breast Cancer in Coordination With SRSF3. PNAS: Proc Natl Acad Sci (2018) 115:E3426-35. doi: 10.1073/pnas. 1714573115

41. Lu H, Guo Y, Gupta G, Tian X. Mitogen-Activated Protein Kinase (MAPK): New Insights in Breast Cancer. J Environ Pathol Toxicol Oncol (2019) 38:51-9. doi: 10.1615/JEnvironPatholToxicolOncol.2018028386

42. Pan D, Kocherginsky M, Conzen SD. Activation of the Glucocorticoid Receptor Is Associated With Poor Prognosis in Estrogen Receptor-Negative Breast Cancer. Cancer Res (2011) 71:6360-70. doi: 10.1158/0008-5472.CAN11-0362

43. Hennessy C, Henry JA, May FE, Westley BR, Angus B, Lennard TW. Expression of the Antimetastatic Gene Nm23 in Human Breast Cancer: An Association With Good Prognosis. J Natl Cancer Inst (1991) 83:281-5. doi: 10.1093/jnci/83.4.281

44. Li S, Shen Y, Wang M, Yang J, Lv M, Li P, et al. Loss of PTEN Expression in Breast Cancer: Association With Clinicopathological Characteristics and Prognosis. Oncotarget (2017) 8:32043-54. doi: 10.18632/oncotarget.16761

45. Viotto D, Russo F, Anania I, Segatto I, Rampioni Vinciguerra GL, Dall'Acqua A, et al. CDKN1B Mutation and Copy Number Variation are Associated With Tumor Aggressiveness in Luminal Breast Cancer. Pathology (2021) 253:23445. doi: $10.1002 /$ path.5584

46. Crowe DL, Chandraratna RAS. A Retinoid X Receptor (RXR)-Selective Retinoid Reveals That RXR- $\alpha$ Is Potentially a Therapeutic Target in Breast Cancer Cell Lines, and That it Potentiates Antiproliferative and Apoptotic Responses to Peroxisome Proliferator-Activated Receptor Ligands. Breast Cancer Res (2004) 6:R546. doi: 10.1186/bcr913

47. Liu H, Gruber CW, Alewood PF, Möller A, Muttenthaler M. The Oxytocin Receptor Signalling System and Breast Cancer: A Critical Review. Oncogene (2020) 39:5917-32. doi: 10.1038/s41388-020-01415-8

48. Goel S, DeCristo MJ, McAllister SS, Zhao JJ. CDK4/6 Inhibition in Cancer: Beyond Cell Cycle Arrest. Trends Cell Biol (2018) 28:911-25. doi: 10.1016/ j.tcb.2018.07.002

49. Collins LC, Cole KS, Marotti JD, Hu R, Schnitt SJ, Tamimi RM. Androgen Receptor Expression in Breast Cancer in Relation to Molecular Phenotype: Results From the Nurses' Health Study. Modern Pathol (2011) 24:924-31. doi: 10.1038/modpathol.2011.54

50. Hickey TE, Robinson JLL, Carroll JS, Tilley WD. Minireview: The Androgen Receptor in Breast Tissues: Growth Inhibitor, Tumor Suppressor, Oncogene? Mol Endocrinol (2012) 26:1252-67. doi: 10.1210/me.2012-1107

51. Hickey TE, Selth LA, Chia KM, Laven-Law G, Milioli HH, Roden D, et al. The Androgen Receptor Is a Tumor Suppressor in Estrogen ReceptorPositive Breast Cancer. Nat Med (2021) 27:310-20. doi: 10.1038/s41591020-01168-7

52. Guiu S, Mollevi C, Charon-Barra C, Boissière F, Crapez E, Chartron E, et al. Prognostic Value of Androgen Receptor and FOXA1 Co-Expression in nonMetastatic Triple Negative Breast Cancer and Correlation With Other Biomarkers. Br J Cancer (2018) 119:76-9. doi: 10.1038/s41416-018-0142-6
53. Robinson JL, MacArthur S, Ross-Innes CS, Tilley WD, Neal DE, Mills IG, et al. Androgen Receptor Driven Transcription in Molecular Apocrine Breast Cancer Is Mediated by Foxal. EMBO J (2011) 30:3019-27. doi: 10.1038/ emboj.2011.216

54. Kensler KH, Beca F, Baker GM, Heng YJ, Beck AH, Schnitt SJ, et al. Androgen Receptor Expression in Normal Breast Tissue and Subsequent Breast Cancer Risk. NPJ Breast Cancer (2018) 4:33. doi: 10.1038/s41523-018-0085-3

55. Jordan A. Toxicology of Progestogens of Implantable Contraceptives for Women1 1From Reviews of Data Submitted to the US FDA to Support NDA. Contraception (2002) 65:3-8. doi: 10.1016/S0010-7824(01)00283-9

56. Lanari C, Molinolo AA, Pasqualini CD. Induction of Mammary Adenocarcinomas by Medroxyprogesterone Acetate in BALB/c Female Mice. Cancer Lett (1986) 33:215-23. doi: 10.1016/0304-3835(86)90027-3

57. Frank DW, Kirton KT, Murchison TE, Quinlan WJ, Coleman ME, Gilbertson TJ, et al. Mammary Tumors and Serum Hormones in the Bitch Treated With Medroxyprogesterone Acetate or Progesterone for Four Years. Fertil Steril (1979) 31:340-6. doi: 10.1016/S0015-0282(16)43886-0

58. McCormack VA, dos Santos Silva IJCE, Biomarkers P. Breast Density and Parenchymal Patterns as Markers of Breast Cancer Risk: A Meta-Analysis. Cancer Epidemiol Biomarkers Prev (2006) 15:1159-69. doi: 10.1158/10559965.EPI-06-0034

59. Boyd NF, Rommens JM, Vogt K, Lee V, Hopper JL, Yaffe MJ, et al. Mammographic Breast Density as an Intermediate Phenotype for Breast Cancer. Lancet Oncol (2005) 6:798-808. doi: 10.1016/S1470-2045(05)70390-9

60. Williams AD, So A, Synnestvedt M, Tewksbury CM, Kontos D, Hsiehm M-K, et al. Mammographic Breast Density Decreases After Bariatric Surgery. Breast Cancer Res Treat (2017) 165:565-72. doi: 10.1007/s10549-017-4361-y

61. Masala G, Assedi M, Ambrogetti D, Sera F, Salvini S, Bendinelli B, et al. Physical Activity and Mammographic Breast Density in a Mediterranean Population: The EPIC Florence Longitudinal Study. Int J Cancer (2009) 124:1654-61. doi: 10.1002/ijc.24099

62. Lundström E, Wilczek B, von Palffy Z, Söderqvist G, von Schoultz B. Mammographic Breast Density During Hormone Replacement Therapy: Differences According to Treatment. Am J Obstet Gynecol (1999) 181:34852. doi: 10.1016/S0002-9378(99)70560-0

63. Lundström E, Christow A, Kersemaekers W, Svane G, Azavedo E, Söderqvist G, et al. Effects of Tibolone and Continuous Combined Hormone Replacement Therapy on Mammographic Breast Density. Am J Obstet Gynecol (2002) 186:717-22. doi: 10.1067/mob.2002.121896

64. Mousa NA, Crystal P, Wolfman WL, Bedaiwy MA, Casper RF. Aromatase Inhibitors and Mammographic Breast Density in Postmenopausal Women Receiving Hormone Therapy. Menopause (2008) 15:875-84. doi: 10.1097/ gme.0b013e31816956c3

65. Cuzick J, Warwick J, Pinney E, Duffy SW, Cawthorn S, Howell A, et al. Tamoxifen-Induced Reduction in Mammographic Density and Breast Cancer Risk Reduction: A Nested Case-Control Study. JNCI: J Natl Cancer Inst (2011) 103:744-52. doi: 10.1093/jnci/djr079

66. Brisson J, Brisson B, Coté G, Maunsell E, Bérubé S, Robert JJCE, et al. Tamoxifen and Mammographic Breast Densities. Cancer Epidemiol Biomarkers Prev (2000) 9:911-5.

67. Engmann NJ, Scott CG, Jensen MR, Ma L, Brandt KR, Mahmoudzadeh AP, et al. Longitudinal Changes in Volumetric Breast Density With Tamoxifen and Aromatase Inhibitors. Cancer Epidemiol Biomarkers Prev (2017) 26:9307. doi: 10.1158/1055-9965.EPI-16-0882

68. Salazar AS, Rakhmankulova M, Simon LE, Toriola AT. Chemoprevention Agents to Reduce Mammographic Breast Density in Premenopausal Women: A Systematic Review of Clinical Trials. JNCI Cancer Spectr (2021) 5:pkaa125. doi: 10.1093/jncics/pkaa125

69. Persson I, Thurfjell E, Holmberg L. Effect of Estrogen and Estrogen-Progestin Replacement Regimens on Mammographic Breast Parenchymal Density. J Clin Oncol (1997) 15:3201-7. doi: 10.1200/JCO.1997.15.10.3201

70. Greendale GA, Reboussin BA, Slone S, Wasilauskas C, Pike MC, Ursin G. Postmenopausal Hormone Therapy and Change in Mammographic Density. JNCI: J Natl Cancer Inst (2003) 95:30-7. doi: 10.1093/jnci/95.1.30

71. McTiernan A, Martin CF, Peck JD, Aragaki AK, Chlebowski RT, Pisano ED, et al. Estrogen-Plus-Progestin Use and Mammographic Density in Postmenopausal Women: Women's Health Initiative Randomized Trial. JNCI: J Natl Cancer Inst (2005) 97:1366-76. doi: 10.1093/jnci/dji279 
72. Lundström E, Söderqvist G, Svane G, Azavedo E, Olovsson M, Skoog L, et al. Digitized Assessment of Mammographic Breast Density in Patients Who Received Low-Dose Intrauterine Levonorgestrel in Continuous Combination With Oral Estradiol Valerate: A Pilot Study. Fertil Steril (2006) 85:989-95. doi: 10.1016/j.fertnstert.2005.09.026

73. Gossner J. Marked Increase of Breast Density Due to a LevonorgestrelReleasing Intrauterine Device. JBR-BTR (2013) 96:396. doi: 10.5334/jbrbtr.529

74. Dillis CL, Schreiman JS. Change in Mammographic Breast Density Associated With the Use of Depo-Provera. Breast J (2003) 9:312-5. doi: 10.1046/j.15244741.2003.09413.x

75. Sobczuk A, Stefańczyk L, Pertyński T, Stetkiewicz T. Evaluation of Micronized Progesterone Influence on Breast Density. Menopause Rev/Przeglad Menopauzalny (2004) 3:45-50 https://www.termedia.pl/Evaluation-ofmicronized-progesterone-influence-on-breast density,4,2165,0,1.html.

76. Chlebowski RT, Rohan TE, Manson JE, Aragaki AK, Kaunitz A, Stefanick ML, et al. Breast Cancer After Use of Estrogen Plus Progestin and Estrogen Alone: Analyses of Data From 2 Women's Health Initiative Randomized Clinical Trials. JAMA Oncol (2015) 1:296-305. doi: 10.1001/jamaoncol.2015.0494

77. Marchbanks PA, McDonald JA, Wilson HG, Folger SG, Mandel MG, Daling JR, et al. Oral Contraceptives and the Risk of Breast Cancer. N Engl J Med (2002) 346:2025-32. doi: 10.1056/NEJMoa013202

78. Kumle M, Weiderpass E, Braaten T, Persson I, Adami H-O, Lund E. Use of Oral Contraceptives and Breast Cancer Risk: The Norwegian-Swedish Women's Lifestyle and Health Cohort Study. Cancer Epidemiol Prev Biomarkers (2002) 11:1375-81.

79. Strom BL, Berlin JA, Weber AL, Norman SA, Bernstein L, Burkman RT, et al. Absence of an Effect of Injectable and Implantable Progestin-Only Contraceptives on Subsequent Risk of Breast Cancer. Contraception (2004) 69:353-60. doi: 10.1016/j.contraception.2003.12.015

80. Li CI, Beaber EF, Tang MTC, Porter PL, Daling JR, Malone KE. Effect of Depo-Medroxyprogesterone Acetate on Breast Cancer Risk Among Women 20 to 44 Years of Age. Cancer Res (2012) 72:2028-35. doi: 10.1158/00085472.CAN-11-4064

81. Soini T, Hurskainen R, Grénman S, Mäenpää J, Paavonen J, Joensuu H, et al. Levonorgestrel-Releasing Intrauterine System and the Risk of Breast Cancer: A Nationwide Cohort Study. Acta Oncol (2016) 55:188-92. doi: 10.3109/ 0284186X.2015.1062538

82. Sweeney C, Giuliano AR, Baumgartner KB, Byers T, Herrick JS, Edwards SL, et al. Oral, Injected and Implanted Contraceptives and Breast Cancer Risk Among U.S. Hispanic and non-Hispanic White Women. Int J Cancer (2007) 121:2517-23. doi: 10.1002/ijc.22970

83. Samson M, Porter N, Orekoya O, Hebert JR, Adams SA, Bennett CL, et al. Progestin and Breast Cancer Risk: A Systematic Review. Breast Cancer Res Treat (2016) 155:3-12. doi: 10.1007/s10549-015-3663-1

84. Luukkainen $\mathrm{T}$, Lähteenmäki $\mathrm{P}$, Toivonen J. Levonorgestrel-Releasing Intrauterine Device. Ann Med (1990) 22:85-90. doi: 10.3109/ 07853899009147248

85. Backman T, Rauramo I, Jaakkola K, Inki P, Vaahtera K, Launonen A, et al. Use of the Levonorgestrel-Releasing Intrauterine System and Breast Cancer. Obstetr Gynecol (2005) 106:813-7. doi: 10.1097/01.AOG.00001787 54.88912.b9

86. Dinger J, Bardenheuer K, Minh TD. Levonorgestrel-Releasing and Copper Intrauterine Devices and the Risk of Breast Cancer. Contraception (2011) 83:211-7. doi: 10.1016/j.contraception.2010.11.009

87. Trinh XB, Tjalma WA, Makar AP, Buytaert G, Weyler J, van Dam PA. Use of the Levonorgestrel-Releasing Intrauterine System in Breast Cancer Patients. Fertil Steril (2008) 90:17-22. doi: 10.1016/j.fertnstert.2007.05.033

88. Lockhat FB, Emembolu JE, Konje JC. Serum and Peritoneal Fluid Levels of Levonorgestrel in Women With Endometriosis Who Were Treated With an Intrauterine Contraceptive Device Containing Levonorgestrel. Fertil Steril (2005) 83:398-404. doi: 10.1016/j.fertnstert.2004.07.961
89. Raudaskoski T, Tapanainen J, Tomás E, Luotola H, Pekonen F, Ronni-Sivula $\mathrm{H}$, et al. Intrauterine 10 Microg and 20 Microg Levonorgestrel Systems in Postmenopausal Women Receiving Oral Oestrogen Replacement Therapy: Clinical, Endometrial and Metabolic Response. BJOG (2002) 109:136-44. doi: 10.1111/j.1471-0528.2002.01167.x

90. Westhoff CL, Pike MC. Hormonal Contraception and Breast Cancer. Contraception (2018) 98:171-3. doi: 10.1016/j.contraception.2018.05.002

91. Ma Y, Katiyar P, Jones LP, Fan S, Zhang Y, Furth PA, et al. The Breast Cancer Susceptibility Gene BRCA1 Regulates Progesterone Receptor Signaling in Mammary Epithelial Cells. Mol Endocrinol (Baltimore Md.) (2006) 20:14-34. doi: 10.1210/me.2004-0488

92. Mote PA, Leary JA, Avery KA, Sandelin K, Chenevix-Trench G, Kirk JA, et al. Germ-Line Mutations in BRCA1 or BRCA2 in the Normal Breast are Associated With Altered Expression of Estrogen-Responsive Proteins and the Predominance of Progesterone Receptor a. Genes Chromosomes Cancer (2004) 39:236-48. doi: 10.1002/gcc.10321

93. Davaadelger B, Choi M-R, Singhal H, Clare SE, Khan SA, Kim JJ. BRCA1 Mutation Influences Progesterone Response in Human Benign Mammary Organoids. Breast Cancer Res (2019) 21:124. doi: 10.1186/s13058-019-1214-0

94. Widschwendter M, Rosenthal AN, Philpott S, Rizzuto I, Fraser L, Hayward J, et al. The Sex Hormone System in Carriers of BRCA1/2 Mutations: A CaseControl Study. Lancet Oncol (2013) 14:1226-32. doi: 10.1016/S1470-2045(13) 70448-0

95. Kotsopoulos J, Gronwald J, Karlan BY, Huzarski T, Tung N, Moller P, et al. Hormone Replacement Therapy After Oophorectomy and Breast Cancer Risk Among BRCA1 Mutation Carriers. JAMA Oncol (2018) 4:1059-65. doi: 10.1001/jamaoncol.2018.0211

96. Narod SA, Dubé M-P, Klijn J, Lubinski J, Lynch HT, Ghadirian P, et al. Oral Contraceptives and the Risk of Breast Cancer in BRCA1 and BRCA2 Mutation Carriers. JNCI: J Natl Cancer Inst (2002) 94:1773-9. doi: 10.1093/jnci/ 94.23.1773

97. F.o.S.a.R. Healthcare. FSRH, UK Medical Eligibility Criteria for Contraceptive Use (UKMEC). UK: Royal College of the Obstetricians and Gynaecologists (2016). Available at: https://www.fsrh.org/standards-and-guidance/ukmedical-eligibility-criteria-for-contraceptive-use-ukmec/.

98. Del Pup L, Codacci-Pisanelli G, Peccatori F. Breast Cancer Risk of Hormonal Contraception: Counselling Considering New Evidence. Crit Rev Oncology/ hematol (2019) 137:123-30. doi: 10.1016/j.critrevonc.2019.03.001

99. Gilmore KL, Hardman SM. New FSRH Guideline on the Progestogen-Only Implant. London: British Medical Journal Publishing Group (2021).

100. ACOG. Practice Advisory: Hormonal Contraception and Risk of Breast Cancer. Am Coll Obstetr Gynecol (2018) Available at: https://www.acog.org/en/clinical/ clinical-guidance/practice-advisory/articles/2018/01/hormonal-contraceptionand-risk-of-breast-cancer.

Conflict of Interest: The authors declare that the research was conducted in the absence of any commercial or financial relationships that could be construed as a potential conflict of interest.

Publisher's Note: All claims expressed in this article are solely those of the authors and do not necessarily represent those of their affiliated organizations, or those of the publisher, the editors and the reviewers. Any product that may be evaluated in this article, or claim that may be made by its manufacturer, is not guaranteed or endorsed by the publisher.

Copyright (c) 2021 Mohammed, Mousa, Talaat, Ibrahim and Saber-Ayad. This is an open-access article distributed under the terms of the Creative Commons Attribution License (CC BY). The use, distribution or reproduction in other forums is permitted, provided the original author(s) and the copyright owner(s) are credited and that the original publication in this journal is cited, in accordance with accepted academic practice. No use, distribution or reproduction is permitted which does not comply with these terms. 